\title{
Identifying the Role of Media Technology Advances in Economics
}

\section{Identificación del papel de los avances de la tecnología de los medios en la economía}

\author{
Morteza Karamouzian \\ Ph.D. Student in Media Management, Yazd Branch, Islamic Azad University, Yazd, Iran. \\ ORCID: https://orcid.org/0000-0001-8773-4434
}

\begin{abstract}
Ali Akbar Farhangi *
Ph.D. in Communication and Management, Professor of Islamic Azad University, Science and Research Branch, Tehran, Iran ORCID: https://orcid.org/0000-0002-6306-9537

\section{Hossein Eslami}

Assistant Professor, Department of Management, Yazd Branch, Islamic Azad University, Yazd, Iran.

ORCID: https://orcid.org/0000-0002-0821-1377
\end{abstract}

Received 09-08-20 Revised 10-10-20

* Correspondence

Email:aafarhangi@ut.ac.ir
Accepted 12-11-21 On line 03-04-21

Citation:

Karamouzian M. Farhangi AA. Eslami H. (2021) Identifying the Role of Media Technology Advances in Economics. Propósitos y Representaciones, 9(SPE2), e1089. http://dx.doi.org/10.20511/pyr2021.v9nSPE2.1089 


\section{Summary}

The purpose of this article is to identify the role of media technology development in the economy. In this study, 30 experts in the field of media were used as a sample. The research method is qualitative. Since in this research, there was a need to address the depth of the subject and a deep and comprehensive understanding of media experts, for this reason, the interview method was used. In order for the interviews to have a specific structure, semi-structured interviews have been used. Data were also analyzed through content analysis using maxqda software. In this study, 23 effective factors that determine the positive and negative role of media technologies in the economy were identified, including: information production and increasing economic knowledge, more employment, consumer welfare, reducing economic inequality, reducing political risk, increasing Economic security and efficiency, more control and supervision of people over economic activities, expansion of corporate markets, creation of free online market, innovations and innovations resulting from new technologies increase revenues, increase competition between organizations increase the quality of economic activities, improve and Improving the standards of economic development, public participation in economic activities, expressing people's satisfaction or dissatisfaction with economic activities, spending time on social networks.

Keywords: The role of media technology development, growth of economic activities, qualitative research.

\section{Resumen}

El propósito de este artículo es identificar el papel del desarrollo de la tecnología de los medios en la economía. En este estudio se utilizaron como muestra 30 expertos en el campo de los medios. El método de investigación es cualitativo. Dado que en esta investigación existía la necesidad de abordar la profundidad del tema y una comprensión profunda y comprensiva de los expertos en medios, por ello se utilizó el método de entrevista. Para que las entrevistas tengan una estructura específica, se han utilizado entrevistas semiestructuradas. Los datos también se analizaron mediante análisis de contenido utilizando el software maxqda. En este estudio, se identificaron 23 factores efectivos que determinan el papel positivo y negativo de las tecnologías de los medios en la economía, entre ellos: producción de información y aumento del conocimiento económico, más empleo, bienestar del consumidor, reducción de la desigualdad económica, reducción del riesgo político, aumento de la seguridad económica y eficiencia, mayor control y supervisión de las personas sobre las actividades económicas, expansión de los mercados corporativos, creación de un mercado en línea libre, innovaciones e innovaciones resultantes de las nuevas tecnologías aumentan los ingresos, aumentan la competencia entre organizaciones aumentan la calidad de las actividades económicas, mejoran y mejoran los estándares de desarrollo económico, participación pública en actividades económicas, expresión de la satisfacción o insatisfacción de las personas con las actividades económicas, pasar tiempo en las redes sociales.

Palabras clave: El papel del desarrollo de la tecnología de los medios, el crecimiento de las actividades económicas, la investigación cualitativa.

\section{Introduction}

At the age of communication, media is one of the most important tools of development in today's world. With having the largest and widest audience, it is one of the main means of communication in achieving development goals. The term media means agent or carrier, which has been derived from the word "Medium". Media has evolved over time through inventions 
such as radio, television, cinema, and the Internet. Media has high social and cultural impacts on society and can also play an effective role in bringing about positive change in society (Nasir, 2013). With growth and development of media, media technologies also spread rapidly. New media technologies called Web 2.0 include a wide range of web-related communication technologies such as blogs, wikis, online social networks, virtual worlds, and other forms of social media (Friedman \& Friedman, 2008). In old days, economists studied and evaluated economic growth based on accumulation of physical factors of production, land, workforce, and capital of machinery and buildings. In middle of the twentieth century, it was revealed that such an analysis could explain only a small part of growth of economic production. However, experience suggests that growth can continue indefinitely, and it was revealed soon that technology progress and development is a missing ring that brings about economic growth and development. Unlike workforce and capital, information is a public good that is distributed by media. It means that using information by one person does not reduce its availability to others (Cunningham et al., 2015). For this reason, new media technologies have found particular importance in recent times. Even NASA uses SecondLife as a tool for cooperation among its personnel (Kaplan, 2007).

\section{Statement of problem}

Population abundance, special conditions of industrial civilization and complexity of social life, national and international dependencies and solidarities, insecurity and crises, evolution of political and social systems, abandonment of old traditions and more importantly awakening of social conscience are all factors that increasing human needs to gain knowledge and awareness of all current events and happenings in the living environment. Based on statistic reported by researchers, the use of new technologies in the media area is increasing sharply. For example, based on one of the statistics reported in this area, membership in new online media in the United States has increased from 33\% to 58\%, while, this rate has increased from $64 \%$ to $75 \%$ and from $47 \%$ to $68 \%$ in Brazil and China, respectively (Hutton \& Fosdick, 2011). It suggests that new media technologies turn to be a new channel for raising human and intellectual capital and these media can be used for learning, knowledge sharing and knowledge acquisition. New technologies allow the media to process information and provide information and news to its users more quickly. Hence, it absorbs more audiences and receives faster feedback. Media need to adapt to new information and communication technologies to survive (Assaad \& Gomez, 2011). In this regard, many researchers argue that, new media technologies play a significant role in the economic area. Based on the statistics, new media technologies such as social networks of Facebook and Twitter have increased advertising revenue of the companies since March 2014, indicating an increase in the economic value of these companies. New media technologies make it possible to exchange data. They have brought huge revenues for companies through online shopping through collecting information about potential customers related to their specific interests (Noff, 2011).

\section{Research objectives}

The general objective of this research is to identify the role of media technology developments and advances in the economy.

\section{Research question}

What is the role of media technology developments and advances in economy?

Theoretical foundations and review of literature 


\section{Definition of media}

The term "media" has been derived from the term "Medium" that means carrier or mode. Media represents a product that is specifically designed to achieve great audiences or viewers. This term was first used with the advent of newspapers and magazines (Nasir, 2013).

\section{The concept of new media technologies}

The term of new media technologies, often referred to as Web 2.0, includes a wide range of web-related communication technologies such as blogs, wikis, online social networks, virtual worlds and other forms of social media. The term "new media" is used everywhere in different ways. (Lievrouw \& Livingstone, 2002) argue that new media technologies include message (i.e., communication and its methods), technology and social context in which it is used. These three aspects of new media technologies are often seen in the literature along with other more specific technologies and practices such as cooperation, digitalization, and telecommunications. (Kavoura \& Stavrianea, 2014) consider new media technologies as a kind of rivalry to old media.

\section{Background of the Study}

In a 2017 study entitled "Sharing economy in social media: Analyzing tensions between market and non-market logic", Laurell \& Sandström raised the question of how the shared economy is formed and who are the main actors in the current movements? By using social media in institutional analysis, the formation of a sharing economy in Sweden, its factors and their impact are followed. Results suggest that sharing economy in Sweden at present includes a wide range of non-market and market activities. Debates on trade and the role of investment companies and the emergence of market logic have brought stability for market (Laurell \& Sandström, 2017). Based on a study conducted by Geissinger et al. in 2017 under the title of "Uber digital disruptions in detection of digital economy", the sharing economy can be considered a common innovation that increases highly throughout society. The existing literature on sharing economy is mainly related to Uber. The aim of this article is to find out what sectors of economy are expected to generate traction. Results refer to a wide range of sharing economy and thus provide a set of concepts and strategies for companies (Geissinger et al., 2017). Using information obtained from membership in social networks, it is observed that social media had a significant negative impact on economic growth (Dell'Anno et al., 2016). In a study entitled "The effect of Internet technology on economic growth in South Asia with a special emphasis on Pakistan", Tufail concluded that the use of the Internet as a new communication and media technology has a positive long-term impact on economic growth and the Internet must be used effectively to have a significant impact on the economic growth of the country (Tufail, 2015). In a study entitled "The effect of Internet on economic growth: evidence from panel data of countries," (Choi \& Yi, 2009) used evidence from a panel of 207 countries from 1991 to 2000 to find evidence that Internet as a new information and media technology plays a major role in economic growth after the investment ratio, government consumption ratio and as control variables in the growth equation in the country. (Salahuddin \& Alam, 2015) investigated Internet use, trade openness, and economic growth in Australia. The results revealed that long-term use of the Internet encourages economic growth. This study also revealed that trade openness has a positive but negligible long-term effect on economic growth. In study entitled "The effect of mobile phones on economic growth in developing countries," (Waverman et al., 2005) showed the positive effects of mobile phones in developing countries are twice as high as in developed countries. In a study entitled "Economic aspects of media globalization", (Rutovic, 2016) examined an important part of the globalization process that deals with relationship between economics and media. 
The economic effects of media explain globalization through negative external consequences in both mutual relationships: global and local, transnational and national, public and private, media and meta-media. This issue starts from two hypotheses: 1) The strength and intensity of these relationships is created through the influence of concentration of organizational media or the convergent interests of media, politics and business and 2) There is a priorities for economic incentives and large capital incentives in relation to other political, social, cultural, media, etc. interests. The research results confirmed these hypotheses.

In a study entitled "The role of provincial national media networks in the economic development of province", (Demirchi, 2016) stated that at the age of communication, the media is one of the most important development tools in today's world. The question raised in the present study is what is the status of provincial networks in realization and achievement of economic development of the provinces? In other words, can provincial networks provide the conditions for economic development? In this study, documentary and library methods were used. Economic development experts believe that economic development is not possible unless social development is realized and social development requires expansion of education and information. Thus, it must be acknowledged that mass media will have a definite impact on cultural development and consequently economic development. Therefore, provincial networks of the national media can provide suitable conditions for economic development of provinces. Saber Sheikh and Hosseini Dana conducted a study in 2014 under the title of "Investigating the role of media in production of economic security" and the results revealed that the significance level of test was less than the alpha value of the test (0.05), meaning that the mass media plays a constructive role in production of economic security, and it is achieved through cooperation of financial institutions. Mass media play a constructive role in reducing economic tensions and can reduce the pressures caused by these tensions (Saber Sheikh \& Hosseini Dana, 2014). In a study entitled "The role of media in the development process: focusing on media and publications", (Afgheh \& Shafiei, 2013) reviewed the concept of development and stages of its evolution from its beginning to the present day. They finally concluded that development is a comprehensive concept that includes social, cultural, political and economic dimensions that can be achieved only by changing the insights and attitudes of people in a society. In a study entitled "The role of provincial media in economic development and paving the way for investment in Zanjan Province", Afgheh \& Shafiei concluded that the provincial media has a direct and indirect impact on economic development. He also stated that by identifying and promoting investment opportunities and advantages in Tarom, Abhar, Khorram Dareh, Ijrud, Mahneshan, Zanjan, Khodabandeh counties, media provide more opportunities for investment (Afgheh \& Shafiei, 2013).

\section{Materials and Methods}

The main method of research in this study is qualitative content analysis method. Accordingly, grounded theory is used to obtain a brief description of the experiences, attitudes and perceptions of interviewees on role of new media technologies in the economy. The grounded theory was first proposed by Glaser and Strauss to construct a theory based on data collected from the research field (ImashevaI \& Kramin, 2020). Grounded theory has three main elements, of concepts, categories and propositions. Concepts are in fact the main units that are obtained at this stage by comparing, labeling events or relationships between phenomena. Categories are the second element of the grounded theory. Categories have a higher level and are more abstract than the concepts they represent (ImashevaI \& Kramin, 2020). Propositions are the third element of grounded theory. Propositions represent generalized relationships between a category and its concepts as well as between discontinuous developments (Kazienko et al., 2011). Theoretical sampling method was used to select the appropriate sample in the qualitative section. Researchers refer to the concepts of validity and reliability to show the quality of their studies (Laren Rachel \& Denise Haunani, 2014). For the qualitative part of the research, many 
criteria have been introduced by researchers. In this study, the four criteria introduced by (ImashevaI \& Kramin, 2020), including credibility, transferability, confirmability, and consistency or dependability were used. Methods such as long-term researcher engagement and peer debriefing were used to ensure the credibility of the data collection process. To increase the transferability or generalizability, in the final report of the research, efforts were made to provide significant information about the characteristics of the environment and the context in which the research was conducted and some information about the participants. Also, to increase the confirmability, efforts were made to reflect the audit mechanisms of research, such as providing documentation on raw data, data reduction process and information analysis, and finally the method of extracting components and dimensions to provide the correctness of the decisions taken on the test. In this research, the review strategy during coding will be done through a detailed review and repeated reviews of the data, interpretations and findings of this study with a look at previous studies. This strategy leads to "confirmability" of the research, which indicates the extent to which the researcher findings are confirmed by other people who review the research or its results. In the qualitative research, the appropriateness of sample indicates that those subjects who have the best knowledge about the research topic should be used as sample of study. In grounded theory, data analysis will be performed in three stages of open coding (category identification), axial coding, and selective coding (final category selection) (ImashevaI \& Kramin, 2020). To analyze the data, first the data were analyzed through interviews and through qualitative methods using Maxqda software.

\section{Results}

The general aim of the present study was to identify the role of media technologies development in the economy based on grounded theory approach. This study had one main question and its interview questions were in line with the exploration of the interview questions. Participants' answers were divided into first level and second level categories after three stages of open, axial and selective coding analysis. This data were divided into 23 first level categories and 14 second level categories.

Table 1. Extracted categories

\begin{tabular}{|c|c|c|}
\hline Row & First level categories & Second level categories \\
\hline 1 & $\begin{array}{l}\text { New communication and media technologies such } \\
\text { as the Internet play a major role in development of } \\
\text { economic knowledge. }\end{array}$ & $\begin{array}{l}\text { Generating information and } \\
\text { enhancing economic } \\
\text { knowledge }\end{array}$ \\
\hline 2 & $\begin{array}{l}\text { New technologies have increased the penetration } \\
\text { of knowledge throughout the country and have } \\
\text { positive impacts on economic growth. }\end{array}$ & \\
\hline 3 & $\begin{array}{l}\text { Providing information improves information for } \\
\text { making economic decisions }\end{array}$ & \\
\hline 4 & $\begin{array}{l}\text { Development of related media technologies leads } \\
\text { to significant advances in access to information, } \\
\text { which in turn paves the way for workforce market } \\
\text { search and adaptation processes. }\end{array}$ & More employment of people \\
\hline 5 & $\begin{array}{l}\text { New media technologies create high employment } \\
\text { in the IT sectors of the economy due to the } \\
\text { economic activity produced. }\end{array}$ & \\
\hline 6 & Communication technologies create additional & \\
\hline
\end{tabular}




\begin{tabular}{|c|c|c|}
\hline & $\begin{array}{l}\text { flexibility in the workforce market. This type of } \\
\text { media, especially remote media, can bring people } \\
\text { into the workforce who might otherwise not have a } \\
\text { job opportunity in their geographical area. }\end{array}$ & \\
\hline 7 & $\begin{array}{l}\text { Rapid development of media and communication } \\
\text { technologies can also have a negative impact on } \\
\text { general employment by changing the demand for } \\
\text { different types of work and the effects savings in } \\
\text { workforce }\end{array}$ & \\
\hline 8 & $\begin{array}{l}\text { More efficient search mechanisms to find } \\
\text { information and better availability to evaluate a } \\
\text { particular product can lead to lower prices for } \\
\text { some consumer goods }\end{array}$ & Consumer welfare \\
\hline 9 & $\begin{array}{l}\text { Consumers also benefit from new ways to meet } \\
\text { consumer needs online, often at very low cost (e.g., } \\
\text { email) or completely new products or services. }\end{array}$ & \\
\hline 10 & $\begin{array}{l}\text { Development of the Internet is also associated with } \\
\text { some security and privacy threats to consumers, } \\
\text { which in turn can reduce consumer welfare. }\end{array}$ & \\
\hline 11 & $\begin{array}{c}\text { Development of new technologies has reduced } \\
\text { inequalities by creating equal economic } \\
\text { opportunities. }\end{array}$ & $\begin{array}{l}\text { Reducing economic } \\
\text { inequalities }\end{array}$ \\
\hline 12 & $\begin{array}{l}\text { The created stability will lead to economic } \\
\text { efficiency, reduced political risk, and increased } \\
\text { stability in economic areas }\end{array}$ & $\begin{array}{l}\text { Reducing political risk and } \\
\text { increasing economic } \\
\text { efficiency and security }\end{array}$ \\
\hline 13 & $\begin{array}{l}\text { Reducing the financial abuses of authorities due to } \\
\text { increasing the control and supervision of people } \\
\text { over economic activities }\end{array}$ & $\begin{array}{l}\text { increasing control and } \\
\text { supervision of people over } \\
\text { economic activities }\end{array}$ \\
\hline 14 & $\begin{array}{c}\text { Creating social responsibility for economic } \\
\text { activities }\end{array}$ & \\
\hline 15 & $\begin{array}{l}\text { Companies have started to widely advertise their } \\
\text { products through social networks, and it has had } \\
\text { positive and negative results for companies and has } \\
\text { expanded the companies' market. }\end{array}$ & $\begin{array}{l}\text { expanding the companies' } \\
\text { market }\end{array}$ \\
\hline 16 & $\begin{array}{l}\text { New technologies with their virtual nature have } \\
\text { created an online market. }\end{array}$ & creating an online market \\
\hline 17 & $\begin{array}{l}\text { Creativity created by media development has } \\
\text { increased revenue. }\end{array}$ & $\begin{array}{l}\text { Innovation and creativity } \\
\text { derived from new } \\
\text { technologies increase } \\
\text { revenue }\end{array}$ \\
\hline 18 & $\begin{array}{l}\text { With increased access of people to open market, } \\
\text { competition among companies for better quality }\end{array}$ & $\begin{array}{l}\text { Increased competition among } \\
\text { companies for better quality } \\
\text { and lower prices of products }\end{array}$ \\
\hline
\end{tabular}




\begin{tabular}{|c|c|c|}
\hline \multicolumn{3}{|c|}{ and lower prices of products has increased. } \\
\hline 19 & $\begin{array}{l}\text { As people become aware of their rights in society } \\
\text { through new media, governments are seeking to } \\
\text { improve economic development standards. }\end{array}$ & $\begin{array}{l}\text { improving economic } \\
\text { development standards }\end{array}$ \\
\hline 20 & $\begin{array}{l}\text { In the digital environment, individual opinions of } \\
\text { stakeholders on companies and brands are freely } \\
\text { exchanged, and accordingly public participation } \\
\text { increases. }\end{array}$ & $\begin{array}{l}\text { public participation in } \\
\text { economic activities }\end{array}$ \\
\hline 21 & $\begin{array}{l}\text { With development of new media technologies, } \\
\text { people are increasingly expressing their sense of } \\
\text { satisfaction and dissatisfaction with economic } \\
\text { activities. }\end{array}$ & $\begin{array}{c}\text { Expressing people's } \\
\text { satisfaction or dissatisfaction } \\
\text { with economic activities }\end{array}$ \\
\hline 22 & wasting people time on social networks & spending time on social \\
\hline 23 & $\begin{array}{l}\text { People waste their time in using social media } \\
\text { instead of spending their time for production }\end{array}$ & networks \\
\hline
\end{tabular}

As shown in (Table 1), among all data obtained, 23 categories were identified, which were reduced to 14 categories. Among all data obtained from the interviews of participants, the following phenomena were identified: generating of information and enhancing economic knowledge, more employment of people, consumer welfare, reducing economic inequalities, reducing political risk and increasing economic efficiency, more control and supervision of people on economic activities, expanding company markets, creating free online markets, innovation and creativity derived from new technologies leading to increased revenues, increasing competition among organizations increase quality in economic activities, improving economic development standards, public participation in economic activities, expressing sense of satisfaction or dissatisfaction of people with economic activities.

\section{Discussion}

The research results revealed that new media technologies have both a positive and a negative impact on the economy and industry. One of the impacts of new media technologies on economy and industry is to generate information and enhance people economic knowledge. Results of the present study are in line with results of research conducted by (Afgheh \& Shafiei, 2013) under the title of "The role of media in development process, focusing on media and publications" to examine the role of changing knowledge and insight of individuals and finally concluded that development is a comprehensive concept that includes social, cultural, political and economic dimensions that is achieved only through change in insights and attitude of people to society. It means that development is not limited to economy but is an educational process in human beings that will lead to development of human beings in society and changes in knowledge and insight have an important impact on economic aspects. The study also revealed that another impact of new media technologies is creation of more employment for people, which is in line with a study conducted by (Hassani, 2012). In a study entitled "The role of provincial media in economic development and providing the conditions for investment in Zanjan province", (Hassani, 2012) concluded that provincial media have a direct and indirect impact on economic development. He also reported that the media led to more investment by identifying and promoting investment opportunities and advantages in the cities of Tarom, Abhar, Khorram Darreh, Ijrud, Mahneshan, Zanjan, Khodabandeh and also by creating media projects in villages and cities and promoting local innovation, business education and entrepreneurship and employment of people in the economic sector (Kazienko et al., 2011). 
Consumer welfare is another impact of new media technology that has been confirmed in a study conducted by (Morton, 2006). In addition to the positive impacts of new technologies on economy, they also have a negative impact based on experts' opinions. One of the negative impacts stated by media experts is people membership in virtual networks and media has caused them to waste their time in vain instead of spending their time on production. This result is in line with those of research conducted by (Hutchinson, 2017), which examined the impact of social media on economic growth. Using the information obtained from membership in social networks, it was found that social media has a negative impact on economic growth. Another positive impact of new media technologies was reducing economic inequalities.

\section{Conclusion}

Development of new technologies has reduced inequalities by creating equal economic opportunities. Also, it will reduce the political risk and increase the economic efficiency and security by creating political security in society. Other positive impacts of media technologies include more control and supervision of people over economic activities and expansion of company markets, innovation and creativity derived from new technologies that leads into increased revenues, increasing competition among organizations, increasing the quality of economic activities, improving economic development standards, and increasing public participation in economic activities. In this study, the positive impact of the Internet on economic growth and trade was reported. One study also revealed the important and positive impact of Internet use in trade openness for almost 32 countries. The mentioned study results are in line with those of our study in confirming the impact of new media technologies on the creation of an online free market. These results are also consistent with the results of a study conducted.

\section{References}

Afgheh, S., \& Shafiei, N. (2013). The role of media in development process: Focusing on Media and Publications. Social Development Quarterly, 8(2), 129-140.

Assaad, W., \& Gomez, J. (2011). Social Network in Media opportunties and risk. Interational Journal of Managing Pub sector information and communication technology, 2(1), 13-22.

Choi, C., \& Yi, M. (2009). The effect of the Internet on economic growth: Evidence from crosscountry panel data. Economics Letters, 105(1), 39-41.

Cunningham, S., Flew, T., \& Swift, A. (2015). Media economics. Macmillan International Higher Education, 21(6), 85-96.

Dell'Anno, R., Rayna, T. \& Solomon, O. (2016). Impact of social media on economic growthevidence from social media. Applied Economics Letters, 23(9), 633-636.

Demirchi, R. (2016). The role of provincial national media networks in the economic development of province. International Conference on New Research in Industrial Management and Engineering, 13(4), 125-137.

Friedman, L., \& Friedman, H. (2008). The new media technologies: Overview and research framework, 13(1), 48-62.

Geissinger, A., Laurell, C., \& Öberg, C. (2017). Imitating Airbnb and Uber-On the Interconnectedness of Sharing Economy Platforms and Digital Business Ventures, In 23rd Nordic Workshop on Interorganisational Research, Stavanger, Norway, 6(2), 22-34.

Hassani, R. (2012). The Role of Provincial Media in Economic Development and Preparation for Investment in Zanjan Province. Master Thesis, Islamic Azad University, 13(5), 220239.

Hutchinson, J. (2017). Audience Participation in Media Organisations. The registered company is Springer International Publishing AG, 11(3), 316-328. 
Hutton, G., \& Fosdick, M. (2011). The globalization of social media: Consumer relationships with brands evolve in the digital space. Journal of advertising research, 51(4), 564-570.

Imasheva, I.Y., \& Kramin, T. (2020). Impact of Broadband Internet on the Economic Growth of the Russian Regions, In First International Volga Region Conference on Economics. Humanities and Sports, 19(5), 26-28.

Kaplan, J. (2007). U.S. Patent Application No. 11/365,545.

Kavoura, A., \& Stavrianea, A. (2014). Economic and social aspects from social media's implementation as a strategic innovative marketing tool in the tourism industry. Procedia Economics and Finance, 14(6), 303-312.

Kazienko, P., Musial, K., \& Kajdanowicz, T. (2011). Multidimensional SocialNetwork and Its Application to the Social Recommender System. IEEETransactions on Systems, Man and Cybernetics-Part A: Systems and Humans, 41(4), 36-48.

Laren Rachel, M., \& Denise Haunani, S. (2014). Relational framing theory. In Engaging Theories in Interpersonal Communication: Multiple Perspectives, ed. D. O. Braitwaite and P. Schrodt, 15(2), 115-127.

Laurell, C., \& Sandström, C. (2017). The sharing economy in social media: Analyzing tensions between market and non-market logics. Technological Forecasting and Social Change, 12(5), 58-65.

Lievrouw, L., \& Livingstone, S. (2002). Handbook of new media, Social shaping and consequences of ICTs. Sage, 18(7), 86-97.

Morton, F. (2006). Consumer benefit from use of the internet, Innovation Policy and the Economy, 6(1), 67-90.

Nasir, M. (2013). Department of Communication and Media Studies. Pakistan: Sarhad University of Science \& Information Technology, Peshawar, 15(4), 166-178.

Nasir, M. (2013). Role of media in a developed society. Interdisciplinary Journal of Contemporary Research in Business, 5(2), 407-418.

Noff, A. (2011). What's next in Social Media. Social Media: Part of the Next Web Family, 9(5), 325-340.

Rutovic, Z. (2016). Economic aspects of media globalization. Journal of International Studies, 9(2), 233-243.

Saber Sheikh, Y., \& Hosseini Dana, H. (2014). Investigating the role of media in producing economic security. International Conference on Behavioral Sciences and Social Studies, 14(1), 196-207.

Salahuddin, M., \& Alam, K. (2015). Internet usage, electricity consumption and economic growth in Australia: A time series evidence. Telematics and Informatics, 32(4), 862878.

Tufail, S. (2015). Impact of Internet Technology on Economic Growth in South Asia with Special Reference to Pakistan, Pakistan Journal of Social Sciences (PJSS), 35(2), 777784.

Waverman, L., Meschi, M., \& Fuss, M. (2005). Africa: The impact of mobile phones. The Vodafone Policy Paper Series, 15(2), 16-30. 